\title{
THE AMPHIPOD GAMMARUS FOSSARUM KOCH (CRUSTACEA) AS INTERMEDIATE HOST FOR SOME HELMINTH PARASITES, WITH NOTES ON THEIR OCCURRENCE IN THE FINAL HOST
}

\author{
by
}

MARION J. VAN MAREN

Institute of Taxonomic Zoology, University of Amsterdam, The Netherlands

$\&$

Dép. de Biologie animale et Zoologie, Université Claude Bernard - Lyon I, France

\section{CONTENTS}

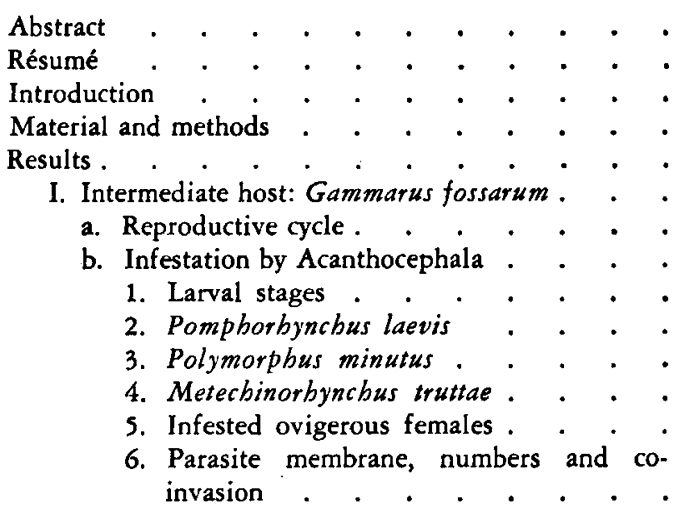

c. Other helminth parasites 102

II. Final host (see appendix I) . . . . . 102

a. Pomphorbynchus laevis . . . . $\quad . \quad 102$

1. Occurrence in fish species. . . . 102

2. Stomach contents . . . . . . 102

3. Sites occupied by adult worms . . . 102

4. Cysts. . . . . . . 102

5. Number of parasites . . . . . 102

6. Sexually mature worms . . . . 102

7. Infestation experiment . . . . . 102

b. Polymorphus minutus . . . . . . 102

c. Other acanthocephalan parasites . . . 103

d. Other helminth parasites . . . . . 103

Discussion . . . . . . . . . . . 104

a. Life cycle of Gammarus fossarum . . $\quad 104$

b. Infestation by Acanthocephala . . . . 104

1. Larval stages . . . . . . . 104

2. Pomphorhynchus laevis. . . . . 104

3. Polymorphus minutus . . . . . 106

4. Other acanthocephalan parasites . . . 106

5. Parasitical castration . . . . . 106

6. Parasite membrane, numbers and coinvasion . . . . . . . . 107

7. Other helminth parasites . . . . 107

Acknowledgements . . . . . . . . . 107

References . . . . . . . . . . . 107

Appendix I. The occurrence of Acanthocephala in dif-

ferent fish species. . . . . . . . . 109

Appendix II. Position of the sampling stations . . 110

\section{ABSTRACT}

Monthly samples of Gammarus fossarum have been taken in the Rhône river system near Lyon, to determine the size composition and reproductive activity throughout the year. The acanthocephalan parasites of this gammarid species were also regularly collected. Furthermore, the intestinal tracts of a number of fishes (amongst others Thymallus tbymallus), feeding mainly on Gammaridae, have been investigated for the presence of helminth parasites.

$G$. fossarum reproduces throughout the year in the area near Lyon, but fluctuations in the rate of ovigerous females appear. A peak in the infestation of the gammarids by larvae of Pomphorbynchus laevis (Acanthocephala) occurred in autumn and a second peak, but a lower one, during spring. The fish hosts showed maximal infestations during the same periods, while during summer the incidence of Pom. laevis was low, both in the intermediate and in the final host.

From the stomach contents of the fishes it seems that gammarids harbouring the invasive acanthocephalan larva (cystacanth) are selectively ingested.

Reproduction of $G$. fossarum seems not always to be inhibited at the presence of acanthocephalan larvae, since several infested female gammarids were found carrying eggs or juveniles in their brood pouch.

The occurrence of some other helminth parasites is recorded for the region near Lyon.

\section{RESUME}

Pendant une année, chaque mois, des prélèvements de Gammarus fossarum ont été effectués dans le bassin du Rhône aux environs de Lyon, afin de déterminer la composition de la population et les cycles de reproduction de cet Amphipode. Des spécimens de Gammares infestés par des larves d'Acanthocéphales ont été récoltés également régulièrement. De plus, le tube digestif de diverses espèces de poissons, qui se nourrissent principalement de Gammares (notamment Thymallus thymallus), a été examiné pour déceler la présence éventuelle de vers parasites.

G. fossarum se reproduit pendant toute l'année dans la région lyonnaise, mais des fluctuations dans le pourcentage de femelles ovigères apparaissent. L'infestation avec Pomphorbynchus laevis (Acanthocephala) montrait un pic maximum en automne, tandis qu'au printemps un pic, de plus faible amplitude, était également constaté. Les poissons montraient une infestation maximum pendant ces mêmes saisons; pendant 
l'été par contre, peu de Pom. laevis furent rencontrés, aussi bien dans l'hôte intermédiaire que dans l'hôte définitif.

D'après l'analyse des contenus stomacaux des poissons, il semble que les Gammares hébergeant la larve infestante d'Acanthocéphales (cystacanthe) soient sélectivement ingérés.

Comme l'infestation de femelles ovigères de $G$. fossarum fut constatée plusieurs fois, la présence de larves d'Acanthocéphales ne semble pas toujours empêcher la reproduction du Gammare.

Quelques autres espèces de vers parasites sont signalées pour la région lyonnaise.

\section{INTRODUCTION}

Ginetsinskaya (1961) states that freshwater amphipods (Gammaridae) act as intermediate hosts for at least 14 helminth parasite species of 4 different groups (Acanthocephala, Trematoda, Cestoda and Nematoda).

According to Croll (1975) a correlation exists between the extent of development in a host and the degree of host specificity. Development of the parasite imposes certain metabolic demands that the host must be able to supply: The metacercaria stage of Trematoda, occurring e.g. in amphipod Crustacea, undergoes no important development in it and is characterized by a wide range of hosts; on the other hand, the development of Acanthocephala, from egg to infective larva, takes place in one host and consequently these parasites have a rather strict preference for their intermediate host. Since acanthocephalans show a relatively wide range of final hosts, the distribution of these worms is usually determined by the distribution of the intermediate host.

For a large number of Acanthocephala, parasitizing fish or waterfowl, benthic Crustacea like Gammaridae serve as intermediate hosts.

Most literature on parasites with larval stages occurring in Amphipoda deals with their presence in the final host and little attention has been paid to the ecology and biology of the amphipod in relation to its rôle as intermediate parasite host.

Several authors have given a description of the development of acanthocephalan species within Gammaridae or other Amphipoda (Awachie, 1966b; Nicholas, 1967; Butterworth, 1969; Podesta \& Holmes, 1970; Crompton, 1970).

LeRoux (1933) referred for the first time to the effect of parasite larvae on the reproduction of their amphipod host, mentioning sterilization of female Gammarus pulex (Linnaeus, 1758) at the presence of the acanthocephalan Polymorphus minutus (Goeze, 1782). In agreement with this are the data of Crompton \& Harrison (1965), who studied Pol. minutus in a wildfowl reserve in Kent. Stark (1965) established sterilization of female Gammarus zaddachi Sexton, 1912, by Diplocotyle (Cestoda) larvae.

Holmes \& Bethel (1972) observed changes in the behaviour of Gammarus lacustris G. O. Sars, 1895, infested by the acanthocephalan Polymorphus paradoxus Connell \& Corner, 1957. The amphipods harbouring cystacanths are strongly positive phototactic and their evasive behaviour is markedly altered; after disturbance, they skim along the surface of the water and/or cling to floating material. Similar behaviour is reported by Stark (1965) for Gammarus zaddachi infested with Diplocotyle larvae.

The influence of the acanthocephalan Pomphorbynchus laevis (Müller, 1776) upon the respiration of its intermediate host, Gammarus pulex, is described by Rumpus \& Kennedy (1974). Data on growth and pigmentation of infested gammarids are provided by Stark (1965) and Hindsbo (1972).

Resistance of Gammarus species and haemocytic reactions towards Polymorphus minutus are studied by Hynes \& Nicholas (1958) and Crompton (1967).

Gauthier (1923) mentions Gammarus pulex as intermediate host for Cyathocephalus truncatus, a cestode causing cyathocephalosis in trout. Baylis (1931) describes several larvae of trout parasites found in G. pulex. Bertocchi \& Francalanci (1963) mention a serious infestation of trout in a fish farm by the acanthocephalan Echinorbynchus truttae, while many $G$. pulex harbouring cystacanth larvae of this parasite were encountered in the same fish ponds.

The present study has been set up to obtain data on the occurrence and infestation rate of the parasites in relation to the life cycle of their gammarid host, Gammarus fossarum Koch, in Panzer, 1836.

\section{MATERIAL AND METHODS}

The present investigations were effectuated during a stay at the Zoological Department of the Univer- 
sity of Lyon. In the Rhône river system, near Lyon, Gammarus fossarum is the most common amphipod species. To establish its size composition and reproductive cycle during a year, monthly samples from a population of $G$. fossarum have been taken in a tributary of the river Rhône, the river Ain, at Gévrieux. Rates of gammarids infested by acanthocephalan larvae, mainly Pomphorbynchus laevis (Müller, 1776), were also determined from these samples. Moreover, infestation rates of $G$. fossarum harbouring larvae of the acanthocephalan Polymorphus minutus (Goeze, 1782) have been established from samples collected monthly in the river Albarine, a tributary of the river Ain.

Part of the sampling of the Amphipoda was carried out with a dip net. This way, though, no gammarids could be collected in the river Rhône itself, because of the depth of this stream. Thanks to the kindness of Mr. J.-F. Perrin and of the "équipe Rhône" of the Zoological Department in Lyon, infested gammarids could be taken from the so-called "paniers" (see Perrin, 1976, for a detailed description of this method, consisting of depositing and lifting limestone-filled waste baskets at regular time intervals in the river).

Preferably, the infested amphipods were selected alive, since colour and shape of the parasites are much less visible after fixation. The gammarids were preserved in $4 \%$ formaldehyde.

After establishing for $G$. fossarum a linear correlation between body length and cephalic length (fig. 1), the latter has been used in determining the composition of the population in the river Ain, where monthly quantitative samples have been collected. The measurements were made under a

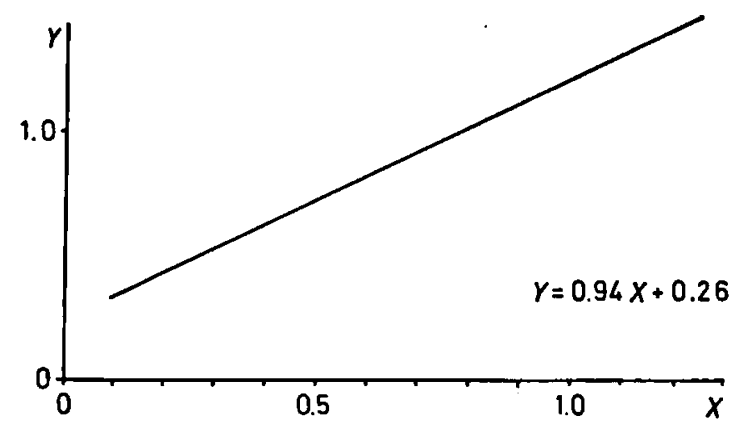

Fig. 1. The relation between cephalic length ( $X$-axis) and body length ( $Y$-axis) in Gammarus fossarum $(N=139$; correlation $=0.957 ;$ standard error $Y=0.025 ;$ standard error $X=0.021$ ). compound microscope with the aid of an eyepiece micrometer (for details on these measurements, see Dennert et al., 1969).

Furthermore, the intestinal tract of a number of fishes, feeding mainly on gammarids, were studied to determine the number and species of helminth parasites. Dr. H. Persat, during his work on the biology of the grayling Thymallus thymallus Linnaeus, 1758 (1976), was so kind as to put a series of fish guts at my disposal for analysis on intestinal parasites. Nearly all fishes were caught by electric fishing. In most cases, the intestines were opened immediately after killing the fish, so that the worms could be obtained alive.

The Acanthocephala were left overnight in tap water at a temperature of $5^{\circ} \mathrm{C}$, allowing them to stretch before fixation. The parasites were fixed in $4 \%$ formaldehyde or A.F.A. (commercial formalin, 10 parts; 95\% ethyl alcohol, 70 parts; glacial acetic acid, 5 parts; distilled water, 15 parts). For the purpose of making microscopical slides (total mountings), the worms were, after fixation, clarified in lactic acid and mounted in Euparal.

In order to get some data on the growth and development of the acanthocephalan Pomphorbyncbus laevis in grayling, gammarids harbouring cystacanth larvae of that parasite were fed to young Thymallus $(15-20 \mathrm{~cm})$ obtained from a fish farm. These fishes were supposed to be free of intestinal parasites, since they had been supplied exclusively with fish pellets. The graylings were kept in basins outside the laboratory, supplied with running water of subterranean origin. During the experiment, that lasted from April till June 1976, temperatures of the water varied from 14 to $15.5^{\circ} \mathrm{C}$. After feeding the fishes with infested $G$. fossarum, weekly some graylings were killed to establish the presence and development of the acanthocephalans. During the experiment the fishes were fed with "SARB" fish pellets, containing neither antibiotics nor antihelminths.

As far as temperature readings have been made during the present study, a mercury thermometer was used (scale in $0.1^{\circ} \mathrm{C}$ ).

The position of the sampling stations where gammarids and/or fishes have been collected, is recorded in appendix II. 


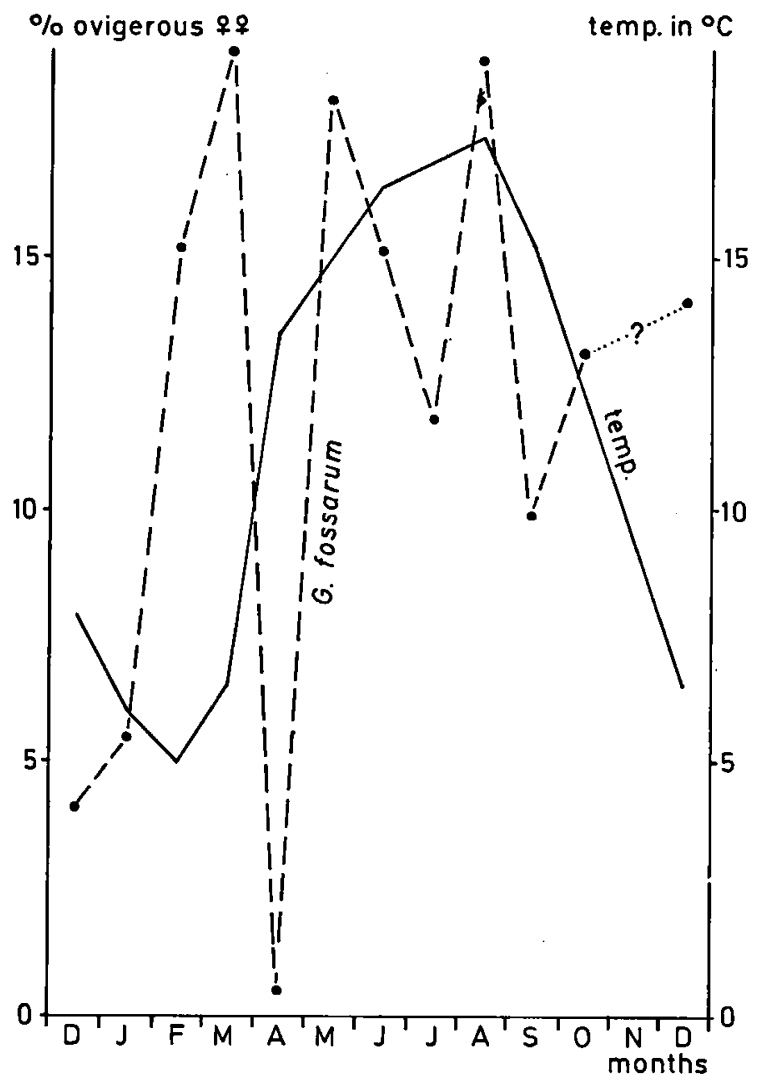

Fig. 2. Percentage of ovigerous $q 9$ (dashed line) in the monthly samples of Gammarus fossarum from the river Ain, during the period Dec. 1975-Dec. 1976. Temperatures of the water (in ${ }^{\circ} \mathrm{C}$ ) are also indicated (solid line).

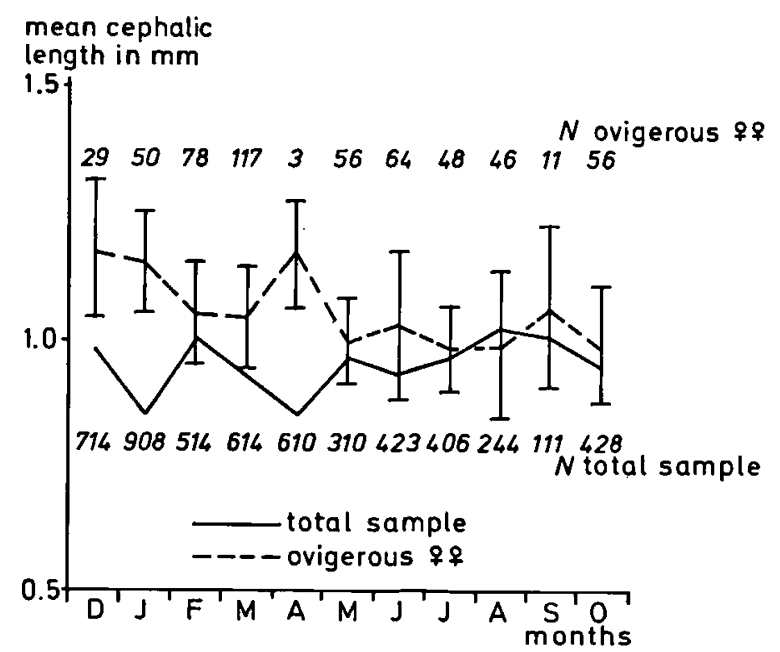

Fig. 3. Mean cephalic length of the specimens of Gammarus fossarum in the monthly samples from the river Ain, during the period Dec. 1975 -Oct. 1976 (bars represent standard deviation). The number of specimens examined is indicated as well,

\section{RESULTS}

I. INTERMEDIATE HOST: GAMMARUS FOSSARUM

a. Reproductive cycle

All monthly samples of Gammarus fossarum from the river Ain contained ovigerous females, although their rate fluctuates throughout the year (fig. 2). In November no samples could be collected, because of the extreme high level of the river.

During the months of January and April minima were found in the mean cephalic length of the G. fossarum population (fig. 3). The ovigerous females were distinctly smaller during summer compared to the rest of the year.

b. Infestation by Acanthocephala 1. Larval stages

The first larval stage of Acanthocephala, the acanthor, emerging from the egg after being swallowed by the arthropod host, was never observed during the present study. This is probably due to its small size and the fact that this larva is located in the intestine or on the outer surface of the gut. The next larval stages, the acanthella and the infective larva, the cystacanth, are lying free in the haemocoel of the host and are much more conspicuous in size and colour. During the present study both stages were encountered throughout the year in Gammarus fossarum, but cystacanths with a somewhat higher frequency than acanthellae.

The great majority of $G$. fossarum harbouring acanthocephalan larvae belonged to the larger size classes of the population.

\section{Pomphorbynchus laevis}

Fig. 4 shows the rates of Gammarus fossarum infested by the acanthocephalan Pomphorbynchus laevis (parasitizing fish) in the monthly samples from the river Ain. From April till August infestation was low. A distinct peak in the infestation rate can be seen in September and another peak, but much lower, occurs in March. In the river Rhône, at Pont de Jons (sta. F), the infestation rate of G. fossarum by Pom. laevis was maximal 2\%, never attaining values as high as in the river Ain.

\section{Polymorphus minutus}

Although the sampling station in the river Albarine (sta. G) is situated on a relatively small 


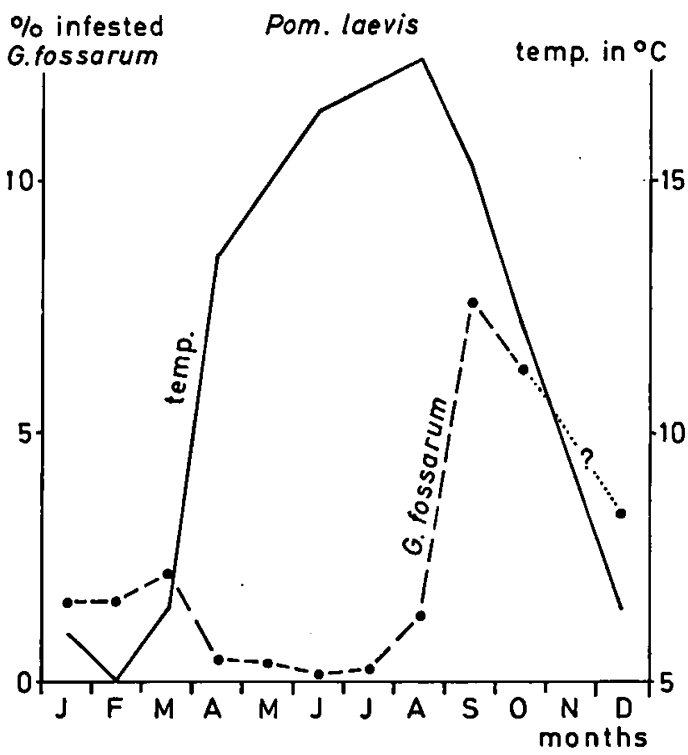

Fig. 4. Percentage of Gammarus fossarum infested by the acanthocephalan Pomphorbynchus laevis (dashed line) in the monthly samples from the river Ain at Gévrieux, during the period Jan.-Dec. 1976. Temperatures of the water (in ${ }^{\circ} \mathrm{C}$ ) are also indicated (solid line).

distance from that in the river Ain, their acanthocephalan faunas show a totally different picture. Most of the year the gammarids from the river Albarine are infested exclusively by larvae of Polymorpbus minutus, a parasite of waterfowl. During January and March peaks in the infestation rate have been established, while infestation was very low from May till September (fig. 5).

An extremely high infestation of Gammarus fossarum by Pol. minutus $(48 \%$ of the total sample!) was observed near the sources of the river Merloux (sta. H). The population of $G$. fossarum is very dense at this locality, situated in a meadow with ducks and chickens. The stream is at the sources not more than $0.3 \mathrm{~m}$ wide and attains a depth of maximal $0.1 \mathrm{~m}$. Not even at $100 \mathrm{~m}$ downstream from the sources, only $2 \%$ of the gammarids was found to be infested and somewhat more downstream the sample did not contain any infested gammarids.

\section{Metechinorbynchus truttae}

Besides Pomphorbynchus laevis and Polymorphus minutus, the prevailing parasite species occurring in gammarids from the Rhône river system, some Gammarus fossarum harbouring larvae of Metechinorbynchus truttae (Schrank, 1788), an acan-

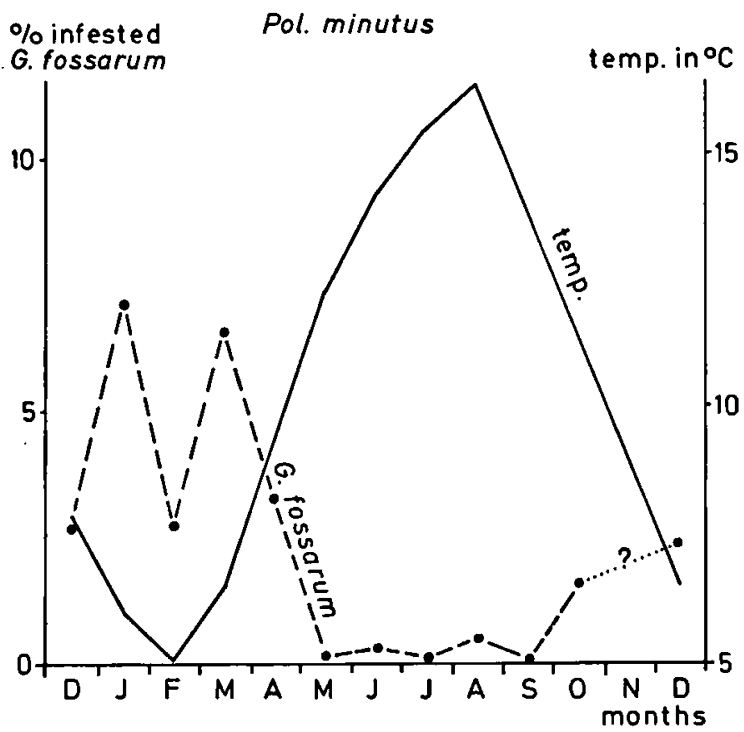

Fig. 5. Percentage of Gammarus fossarum infested by the acanthocephalan Polymorpbus minutus (dashed line) in the monthly samples from the river Albarine at Gévrieux, during the period Dec. 1975- Dec. 1976. Temperatures of the water (in ${ }^{\circ} \mathrm{C}$ ) are also indicated (solid line).

thocephalan parasitizing fish, have been encountered.

\section{Infested ovigerous females}

Not infrequently ovigerous females of Gammarus fossarum were observed harbouring acanthocephalan larvae. Cystacanth larvae of Polymorpbus minutus or Pomphorbynchus laevis occurred in these females. Precopulae have been collected of which one or both partners contained acanthocephalan larvae.

\section{Parasite membrane, numbers and co-invasion} The cystacanths of Polymorpbus minutus were always found to be surrounded by a membrane, transparent and brownish in colour. Around the infective larva of Pomphorbynchus laevis, however, no envelope occurred.

Although gammarids harbouring up to 14 acanthocephalan larvae have been found during the present investigations, most commonly 1 to 3 larvae were encountered in the amphipods.

Gammarus fossarum harboured normally-developed larvae of different acanthocephalan species (combinations of Pol. minutus and Pom. laevis, of Pom. laevis and Metechinorbynchus truttae or of Pol. minutus and M. truttae). 


\section{c. Other helminth parasites}

At several localities in the Rhône river system gammarids infested by larval cestodes were collected. In those cases in which identification was possible Cyathocephalus truncatus (Pallas, 1781) was found.

\section{FINAL HOST (SEE APPENDIX I)}

\section{a. Pompborbynchus laevis}

1. Occurrence in fish species

Pomphorbynchus laevis is the most commonly met helminth species in grayling, Thymallus thymallus (Linnaeus, 1758), from the river Ain (sta. A, B and C) and in barbel, Barbus barbus (Linnaeus, 1758), from the river Albarine (sta. G) (appendix Ia $\&$ b). It has to be noted that in the latter fish species Pom. laevis attains a size much larger than in Thymallus and that its colour is deep-orange instead of the pink-orange of the smaller worms.

Furthermore, Pom. laevis was found in trout, Salmo trutta Linnaeus, 1758, in loach, Noemacheilus barbatulus (Linnaeus, 1758), in roach, $R u$ tilus rutilus (Linnaeus, 1758), and in minnow, Phoxinus phoxinus (Linnaeus, 1758), from the river Ain. In burbot, Lota lota (Linnaeus, 1758), from the river Loue in the Jura (sta. E) and in bullhead, Cottus gobio Linnaeus, 1758, from the river Rhône (sta. F) this parasite occurred as well (appendix Ic).

\section{Stomach contents}

The presence of Pomporbynchus laevis larvae in the stomach contents of their final hosts indicates recent feeding on gammaridean Amphipoda. The stomachs of grayling, caught during summer, contained none or hardly any acanthocephalans; it might be significant that in this season the food of the fish consisted mainly of insect larvae. During the months of October and November the number of cystacanth larvae in the stomach contents of the fishes varied from 17 to 48 , while the food was composed chiefly of Gammarus.

Although mainly the cystacanth stage was found, also some acanthellae (the earlier, non-infective larval stage) of Pom. laevis were observed in the stomachs of grayling.

\section{Sites occupied by adult worms}

Never adult Acanthocephala were observed in the stomachs of the fishes that have been investigated. They occurred always in the intestine proper, and in a few graylings, heavily infested by Pomphorbynchus laevis, several worms were found attached to the liver, gonads or swim bladder.

4. Cysts

Often the outer surface of the intestinal wall of the fishes studied showed cyst-like formations. Upon closer examination these cysts proved to contain the proboscis and part of the neck of Pomphorbynchus laevis.

\section{Number of parasites}

No correlation could be established between the number of Pomphorbynchus laevis occurring in a particular fish and the fish's length (age). It must be noted, though, that only grayling of more than $12 \mathrm{~cm}$ were available for examination. The number of Pom. laevis in the final host is minimal during summer, but in spring and autumn more than 250 specimens have been counted in some fishes (appendix Ia).

\section{Sexually mature worms}

Sexually mature Pomphorbynchus laevis (gravid females) were present in Barbus barbus, but, in spite of the heavy infestations of Thymallus thymallus by this parasite, hardly any ovigerous worms have been observed in this fish species.

\section{Infestation experiment}

Fig. 6 shows adult Pomphorbynchus laevis, obtained from grayling, $1 / 2,2,4,5,7,10$ and 11 weeks after they had been supplied with gammarids harbouring larvae of this parasite. After 4 weeks all worms were fixed to the intestinal wall, while after 7 weeks the formation of a capsule around the proboscis and neck of the parasite was observed. The worms found after 10 weeks were solidly attached to the gut wall, forming a cyst-like structure around the upper part of the acanthocephalan.

\section{b. Polymorpbus minutus}

Since no birds from the Rhône river system have been at our disposal for examination on the pres- 


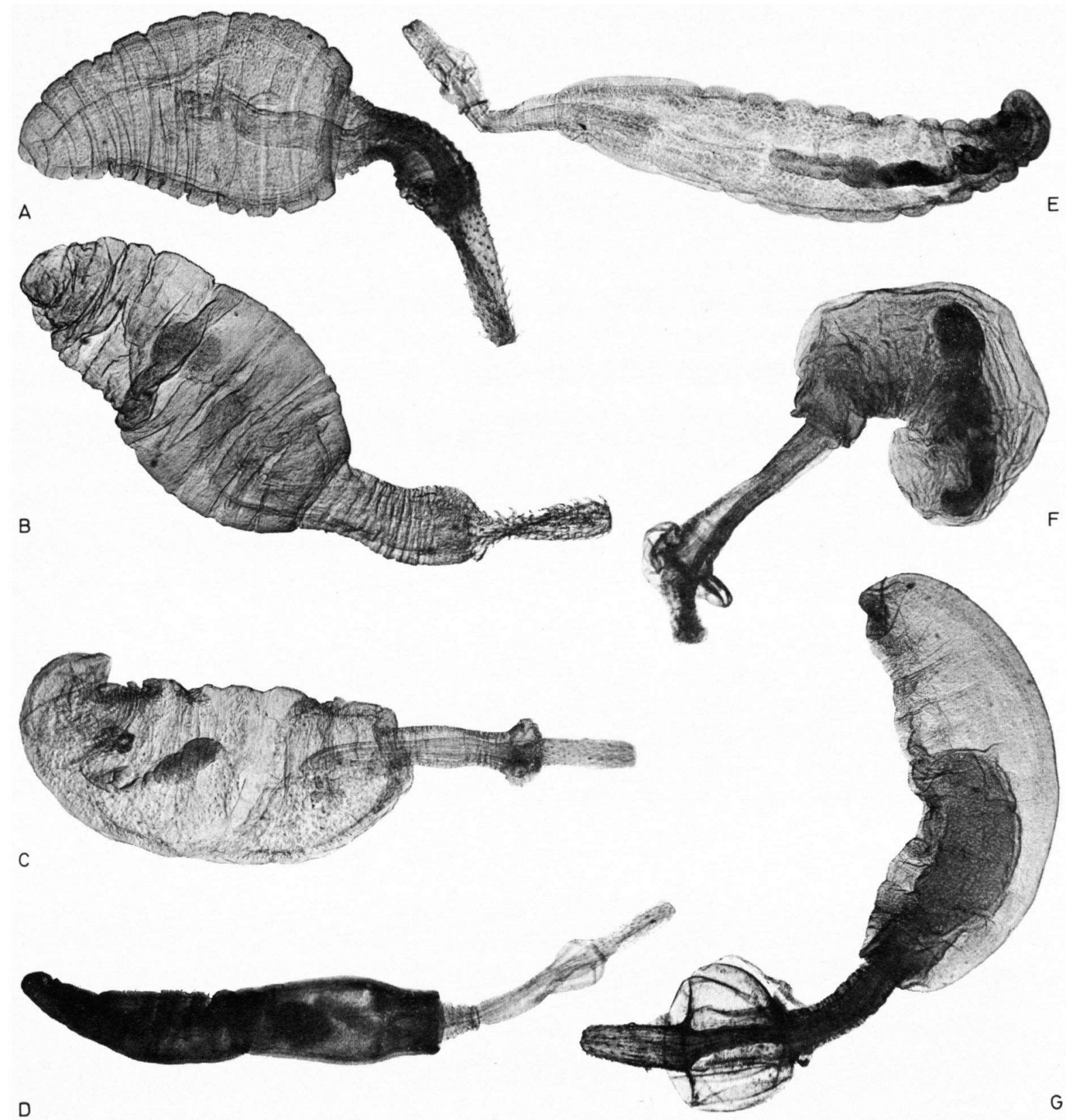

Fig. 6. Adult Pomphorbyncbus laevis obtained from grayling, $1 / 2$ (A), 2 (B), 4 (C), 5 (D), 7 (E), 10 (F) and 11 (G) weeks after the fishes had been fed with gammarids harbouring larvae of this parasite $(19 \times)$.

ence of the parasite Polymorphus minutus, only its occurrence in the gammarid host could be studied.

c. Other acanthocephal an parasites Many Metechinorbynchus truttae have been collected from grayling captured in the river Furans (sta. D), while only a few Pomphorbyncbus laevis occurred in these fishes.
Burbot (Lota lota), captured in the river Loue (sta. E), was heavily infested by Pseudoechinorbynchus clavula (Dujardin, 1845) (appendix Ic).

d. Other helminth parasites

Cyathocephalus truncatus Pallas, 1781, a cestode, was collected in grayling from the river Furans (sta. D) and from the river Ain (sta. B). Both 
larvae and adult worms occurred in the pars pylorica of the intestine, while the former were encountered in the stomach as well.

\section{DISCUSSION}

\section{a. Lif e cycle of Gammarus fossarum}

The results obtained during the present study confirm the observations of Roux (1970), according to which Gammarus fossarum reproduces throughout the year in the waters near Lyon. He supposes that temperature influences the rate of increase or decrease in reproductive activity. The rate of ovigerous females was very low in April compared to the rest of the year (fig. 2). Water temperatures rose from $6.5^{\circ} \mathrm{C}$ in March to $14.5^{\circ} \mathrm{C}$ in April. Although the annual temperature fluctuations seem to influence the rate of ovigerous females, the temperature range in the Rhône river system near Lyon is such that reproduction is possible the whole year round $\left(5^{\circ}-17.4^{\circ} \mathrm{C}\right)$.

Lehman (1967) established that in January the larger, overwintering females of $G$. fossarum, which are already mature, start to breed and that in February the first breeding females of the new generation appear. In agreement with these observations, the ovigerous females from the river $A$ in are smaller in February and March compared to those collected in December and January (fig. 3). During summer only females of small size were found to breed. Consequently, the larger ovigerous females in April still belong to the old, overwintering generation, that dies off in late spring.

\section{b. Infestation by Acanthocephala}

1. Larval stages

The larval stages encountered during the present study in Gammarus fossarum were all acanthellae or cystacanths, but never the earliest acanthor larva. Moreover, in agreement with the observations of Hine \& Kennedy (1974b), small amphipods were rarely found to be infested. Spencer (1974), who studied the infestation of Gammarus lacustris by the acanthocephalan Polymorphus minutus, mentions that acanthors are undoubtedly present in the smaller gammarids, but are not visible because of their small size and location deep in the body of the host.

\section{Pomphorbynchus laevis}

Hine \& Kennedy (1974b) established a general absence of a cycle in the incidence and intensity of infestation in gammarids and fishes by Pomphorbynchus laevis in the river Avon (Great Britain). Infestation of gammarids seems to take place all year round, only in summer the parasite was slightly less common. Although acanthellae (young larvae of Acanthocephala) are found in Gammarus fossarum from the river Ain throughout the year, a distinct minimum in the infestation rate of the gammarids can be seen during late spring and summer (fig. 4). Ginetsinskaya (1961) assumes that the water temperature is a major determining factor in the life cycle of the parasite, regulating both the period of peak reproduction of the intermediate host and the development of the worm within it. It might be concluded in the present case, that temperature affects mainly the development of the parasite, as breeding of $G$. fossarum does not appear to be limited by the temperatures recorded for the Rhône river system.

In Thymallus thymallus from the river Ain large numbers of Pom. laevis were counted during early spring and autumn, while in July and August the fish contained relatively few worms (appendix Ia). Moreover, in summer, contrary to the month of October, only few acanthocephalan larvae were found in the stomachs of grayling (the presence of Acanthocephala in the stomach of the fish indicates recent feeding on infested gammarids!).

Since the acanthella stage (not yet infective larva) was rarely found in the stomach contents of the fish, it might be concluded that mainly gammarids harbouring the infective larva (cystacanth) are eaten by the final hosts. Bethel \& Holmes (1973, 1974), studying Gammarus lacustris infested by the acanthocephalan Polymorphus paradoxus, discovered that a disproportionally large number of infested gammarids, compared to noninfested specimens, was eaten by the final host. Furthermore, they found a correlation between the behaviour of the amphipods and the infectivity of the parasite larvae. They assume that gammarids harbouring the invasive larva, move, as a result of their modified behaviour, into a zone of overlap with the feeding niche of the final host, thus increasing the probability of parasite transmission. 
Selective feeding by the fishes on infested Gammarus, resulting from a modified behaviour of the amphipods harbouring cystacanths and from the conspicuousness of the parasite larva (orange coloured in the case of Pom. laevis), might be an explanation for the heavy infestations by Pom. laevis observed in the fishes from the waters near Lyon.

Grayling lacks pharyngeal teeth and does not masticate its food, so that gammarids arrive still relatively intact in the stomach of the fish. According to Kennedy et al. (1976), Pom. laevis can survive in all parts of the intestinal tract. The sites it occupies in the alimentary canal of the fish are mainly determined by the process of liberation and activation of the worms. Liberation and activation of the cystacanths take place in the pars pylorica of the intestinal tract in grayling. During the present investigations, fixed adult Pom. laevis were always found in the intestine proper, never in the stomach or pyloric region of the fish. It has been observed, though, that the present parasite sometimes penetrates so deep into the intestinal wall, that it passes right through and not seldom it was found to be attached to other organs in the abdominal cavity, such as liver, swim bladder or gonads. Similar observations are mentioned by Dorier (1931), Petrochenko (1971) and Hine \& Kennedy (1974a).

From fig. 6 can be seen that some growth of Pom. laevis took place in grayling during the 3 months' period of the infestation experiment. According to Hine \& Kennedy (1974a) the encapsulation reaction of the fish host towards Pom. laevis is accentuated when the proboscis bulb of the acanthocephalan is well developed. They state that this parasite seldom develops a bulb in $T b y$ mallus. In our studies Pom. laevis showed development of a bulb already 4 weeks after infestation, while in the 11th week a cyst-like formation was found on the intestinal wall, containing the proboscis and neck with bulb of the acanthocephalan.

Most barbels from the river Albarine, examined during the present study, were infested by Pom. laevis (appendix Ib). Sexually mature worms were commonly met in this fish species, but in grayling only on rare occasions. Hine \& Kennedy (1974a) mention that, in spite of the heavy infestations of
Thymallus by Pom. laevis in the river Avon, no gravid females of this parasite occurred in grayling. They suppose that the population of this worm in the river Avon is maintained by eggs of Pom. laevis originating from chub and barbel, which seem to be the preferred final hosts. The presence of Pom. laevis in bullhead (Cottus gobio) and loach (Noemacheilus barbatulus) from the Rhône river system (appendix Ic) is in agreement with the data presented by Rumpus (1975), who observed that maturation of this acanthocephalan is also possible in these fish species. Since maturation of the present parasite seems to be possible in trout as well (Hine \& Kennedy, 1974a), this fish species might maintain the population of Pom. laevis in the river Ain, where it commonly occurs next to grayling.

Concerning the occurrence of Pomphorbynchus laevis in its intermediate and final hosts, the following assumptions are put forward:

- Gammarids harbouring the infective larva (cystacanth) are more often eaten by the fish. This might be a result of the conspicuousness of the larva and/or a possible altered behaviour of the intermediate host.

- Cysts on the intestinal wall of the fishes are provoked by worms having attained already a certain size. Upon loss of the acanthocephalan from the gut, the cyst, containing the neck and proboscis of the worm, remains.

- Sexually mature worms probably die off after some time and are expelled from the intestine. Muzzall \& Rabelais (1975) concluded from their observations concerning Acanthocephalus jacksoni Bullock, 1962, that gravid female worms deteriorate in the environment outside the host and that eggs are released at that moment. Nicholas \& Hynes (1958) came to a similar assumption, since they never found eggs of Polymorphus minutus in the droppings of infested ducks.

- From the number of cystacanths contained in the stomach of the fishes examined, and from the number of worms attached to the gut wall during different seasons, it can be concluded that maximal infestation of the final host takes place during autumn and spring. During these periods large numbers of small Pom. laevis were found in the 
intestines of the fish, indicating recent feeding on infested gammarids.

- Maximum rates of gammarids harbouring acanthella or cystacanth larvae occurred in autumn and spring. It must be assumed that part of the amphipods occurring in spring became infested during the year before, since the development of acanthocephalans is considerably retarded by lower temperatures.

\section{Polymorphus minutus}

The highest infestation rates of Gammarus fossarum from the river Albarine with larvae of Polymorphus minutus, a parasite of waterfowl, occurred in spring, while low rates were found during summer (fig. 5). Hynes (1955) found Pol. minutus to be abundant in samples of gammarids (Gammarus duebeni Liljeborg, 1852 and Gammarus lacustris) from Great Britain taken in summer, less common in autumn and rare or even absent during winter and spring. Spencer (1974), investigating the infestation of Gammarus lacustris with Pol. minutus in ponds that are ice-covered from November till April, established peaks in the infestation percentages in April and August. According to Ginetsinskaya (1961), infestation rates may vary from one locality to another for the same parasite species, since annual cycles of the parasites are related to the hydrology of the host's habitat.

In the river Merloux, near the sources, an infestation rate as high as $48 \%$ was established for G. fossarum harbouring larvae of Pol. minutus, while somewhat more downstream no infested gammarids were found. These observations are in agreement with those of Noll (1950), who found more than $60 \%$ of $G$. fossarum to be infested by the present worm in a small rivulet downstream of a duck farm. Furthermore, he established that infestation of the gammarids was very localized.

The presence of Pol. minutus in the Rhône river system seems to be restricted to those parts of the river, where more or less swampy biotopes are available (e.g. the Vieux Rhône near Lyon). Although the river Albarine is a fast running stream in autumn, winter and spring, in summer it shows a totally different picture: the river largely dries up and consists almost exclusively of stagnant pools, very little running water being left.
Since no birds from the river Albarine have been at our disposal for examination on the presence of Pol. minutus, only its occurrence in the gammarid host could be studied.

4. Other acanthocephalan parasites

The grayling from the river Furans (sta. D) harboured large numbers of the acanthocephalan Metechinorbynchus truttae and only a few Pomphorbynchus laevis. However, no gammarids have been examined from this river. Awachie (1966b) mentions Gammarus pulex as intermediate host for M. truttae in Great Britain. During the present investigations Gammarus fossarum from several localities in the Rhône river system were found to contain larvae of this parasite.

A specimen of Lota lota (burbot) from the river Loue (sta. E) harboured over a hundred individuals of Pseudoechinorbynchus clavula and only one Pom. laevis (appendix Ic). Petrochenko (1971) mentions the amphipods Gammarus pulex and Pontoporeia affinis Lindström, 1855, as intermediate host for Ps. clavula. Chubb (1967) found this parasite in fishes from oligotrophic lakes in the British Isles, where the isopod Asellus meridianus Racovitza, 1919, seems to be its intermediate host.

\section{Parasitical castration}

The effect of acanthocephalan larvae on the reproduction of the intermediate host was first mentioned by LeRoux (1933). She states that females of Gammarus pulex infested by Polymorphus minutus do not reproduce. Especially the vitellogenesis seems to be inhibited by the presence of the parasite larva. According to Goodwin (1960) some Crustacea, such as Gammarus, accumulate large quantities of the carotenoid astaxanthin. At the moment of reproduction a mobilization of this pigment takes place to the eggs. The orangecoloured acanthocephalan larva, containing esterified astaxanthin, obtains its carotenoids from the haemolymph of the amphipod host (Barrett \& Butterworth, 1968). Hynes \& Nicholas (1958) established that females of Gammarus pulex, G. lacustris and G. duebeni, when infested by Pol. minutus, do not reproduce normally.

During the present investigations, several female gammarids infested by Acanthocephala have been 
collected carrying eggs or juveniles in their brood pouch. Very few of these females harboured larvae of Pol. minutus, but ovigerous females with Pomphorbynchus laevis were rather commonly found. According to Crompton (1970), not all developing acanthocephalans castrate their host. Moreover, Spencer (1974), who found many ovigerous females of G. lacustris harbouring Pol. minutus larvae, established that infestation by the parasite, although decreasing the reproductive potential of the amphipod, not always impaired breeding of the females. He mentions two possible explanations: infestation took place after the females formed their egg masses, or parasite and host have come into a state of balance.

\section{Parasite membrane, numbers and co-invasion}

The present investigations show that Polymorphus minutus cystacanths are always surrounded by a membrane, while around the invasive larva of Pomphorbynchus laevis never an envelope was found. According to Crompton (1964) the capsule, surrounding the larva of Pol. minutus, consists of connective tissue and originates from the serosa of the host's gut wall. He assumes that acanthocephalans that stay associated with the intestinal wall of the amphipod host for a longer time do possess capsules: Pol. minutus is associated for several days with the gut wall, while Pom. laevis larvae penetrate through it in a few hours.

In most cases not more than 3 acanthocephalan larvae were present in one gammarid. Petrochenko (1971) states that a high degree of infestation has an adverse effect on the crustaceans. Heavily infested gammarids will die under natural conditions. Seidenberg (1973), who studied the ecology of an acanthocephalan parasite in its intermediate host, an isopod of the genus Asellus, established that the mortality of heavily infested isopods is one of the factors regulating the density of the isopod population.

Since Gammarus fossarum from the Rhône river system was found to harbour normally developed larvae of different acanthocephalan species, invasion of the gammarid host by different Acanthocephala at the same time does not seem to have an adverse effect on the development of the parasite larvae. This confirms the results as mentioned by Awachie (1966b, 1967).

\section{Other helminth parasites}

Vik (1958) has found the cestode Cyathocephalus truncatus in the haemocoel of Gammarus lacustris and G. pulex in Norway. During the present study, larvae of this parasite were observed in $G$. fossarum, but its occurrence was rare compared to that of the acanthocephalan larvae. Awachie (1966a) often found adult $C$. truncatus in trout, but he rarely came across larval stages in Gammarus from the same stream. The occurrence of this worm in the pyloric region of the fish intestine, as established during the present investigations, is in agreement with the data by Gauthier (1923).

\section{ACKNOWLEDGEMENTS}

I am greatly indebted to the French Government for providing me with a grant, which has allowed me to carry out the present study. I want to express my gratitude also to Prof. A. L. Roux of the University of Lyon for the great hospitality I experienced during my stay in his laboratory. Furthermore I owe many thanks to Mr. J.-F. Perrin and Dr. H. Persat for putting amphipod and fish material at my disposal. Thanks are also due to Mr. L. A. van der Laan for making the photographs and to Mr. J. Zaagman for his assistance in preparing the figures. In addition, I am very grateful to Prof. J. H. Stock, to Prof. H. B. N. Hynes, to Drs. F. Pieters and Dr. S. Pinkster for their constructive criticism concerning the preparation of the present paper.

\section{REFERENCES}

AwACHIE, J. B. E., 1966a. Observations on Cyathocephalus truncatus Pallas, 1781 (Cestoda, Spathebothriidae) in its intermediate and definite hosts in a trout stream, North Wales. J. Helminth., 40: 1-10.

,- 1966b. The development and life history of Echinothynchus truttae Schrank, 1788 (Acanthocephala). J. Helminth., 40: 11-32.

- 1967. Experimental studies on some host-parasite relationships of Acanthocephala. Co-invasion of Gammarus pulex L. by Echinorhynchus truttae Schrank, 1788 and Polymorphus minutus (Goeze, 1782). Acta parasit. pol., 15: 69-74.

BARRETT, J. \& P. E. ButTERWORTH, 1968. The carotenoids of Polymorphus minutus (Acanthocephala) and its intermediate host Gammarus pulex. Comp. Biochem. Physiol., 27: 575-581.

BAYLIS, H. A., 1931. Gammarus pulex L. as an intermediate host for trout parasites. Ann. Mag. nat. Hist., (10) 7: 431-435.

Bertocchi, D. \& G. Francalanci, 1963. Grave infestazione da Echinorhynchus truttae Schrank in trote iridee di allevamento (Salmo gairdneri). Veterinar. italian., 14 (5): 475-481.

Bethel, W. M. \& J. C. Holmes, 1973. Altered evasive behaviour and responses to light in amphipods harbouring acanthocephalan cystacanths. J. Parasit., 59: 945-956.

$\longrightarrow \&-$, 1974. Correlation of development of altered evasive behaviour in Gammarus lacustris (Amphipoda) harbouring cystacanths of Polymorphus paradoxus 
(Acanthocephala) with the infectivity to the definitive host. J. Parasit., 60 (2): 272-274.

ButTERWORTH, P. E., 1969. The development of the bodywall of Polymorphus minutus (Acanthocephala) in the intermediate host Gammarus pulex. Parasitology, Cambridge, 59: 373-388.

CHUBB, J. C., 1967. Host specificity of some Acanthocephala of freshwater fishes. Helminthologia, 8: 63-70.

CRoll, N. A., 1975. Ecology of parasites: 1-136 (Heinemann Educational Books, London).

Crompton, D. W. T., 1964. The envelope surrounding Polymorphus minutus (Goeze, 1782) during its development in the intermediate host, Gammarus pulex. Parasitology, Cambridge, 54: 721-735.

- 1967. Studies on the haemocytic reaction of Gammarus spp. and its relationship to Polymorphus minutus (Acanthocephala). Parasitology, Cambridge, 57: 389-401.

- 1970. An ecological approach to acanthocephalan physiology: 1-125 (Cambridge University Press, Cambridge).

Crompton, D. W. T. \& J. G. Harrison, 1965. Observations on Polymorphus minutus (Goeze, 1782) (Acanthocephala) from a wildfowl reserve in Kent. Parasitology, Cambridge, 55: 345-355.

Dennert, H. G., A. L. Dennert, P. Kant, S. Pinkster \& J. H. STOCK, 1969. Ujpstream and downstream migrations in relation to the reproductive cycle and to environmental factors in the amphipod, Gammarus zaddachi. Bijdr. Dierk., 39: 11-43.

Dorier, A., 1931. Infection des Truites arc-en-ciel d'élevage par les Echinorhynques. Trav. Lab. Hydrobiol. Piscic. Univ. Grenoble, 23: 55-60.

GAuTHIER, M., 1923. La cyathocéphalose dans les élevages de truites. Annls. Univ. Grenoble, 34 (2): 201-206.

Ginetsinskaya, T. A., 1961. The life cycles of fish helminths and the biology of their larval stages. In: V. A. Dogiel, G. K. Petrushevski \& Y. I. Polyanski eds., Parasitology of fishes: 140-165 (Oliver \& Boyd, Edinburgh/ London)

GoodwIN, T. W., 1960. Biochemistry of pigments. In: T. H. Waterman ed., Physiology of Crustacea, 1: 101-140 (Academic Press, New York).

HindsBo, O., 1972. Effects of Polymorphus (Acanthocephala) on the colour and behaviour of Gammarus lacustris. Nature, Lond., 283: 333.

Hine, P. M. \& C. R. KENNEDY, 1974a. Observations on the distribution, specificity and pathogenicity of the acanthocephalan Pomphorhynchus laevis (Müller). J. Fish Biol., 6 (4): 521-535.

- \& $-1974 \mathrm{~b}$. The population biology of the acanthocephalan Pomphorhynchus laevis (Müller) in the river Avon. J. Fish Biol., 6 (5): 665-679.

Holmes, J. C. \& W. M. Bethel, 1972. Modification of intermediate host behaviour by parasites. In: E. U. CANNING \& C. A. WRIGHT eds., Behavioural aspects of parasite transmission. Zool. J. Linn. Soc., 51 (Suppl. 1): 123-149, pls. I-II (Linnean Society of London \& Academic Press, London \& New York).

Hynes, H. B. N., 1955. The reproductive cycle of some British freshwater Gammaridae. J. anim. Ecol., 24 (2): 352.387.

HyNes, H. B. N. \& W. L. Nicholas, 1958. The resistance of Gammarus spp. to infection by Polymorphus minutus (Goeze, 1758) (Acanthocephala). Ann. trop. Med. Parasit., 52: 376-385.
Kennedy, C. R., P. F. BRoughton \& P. M. Hine, 1976. The sites occupied by the acanthocephalan Pomphorhynchus laevis in the alimentary canal of fish. Parasitology, Cambridge, 72: 195-206.

Lehman, U., 1967. Drift und Populationsdynamik von Gammarus pulex fossarum Koch. Z. Morph. Ökol. Tiere, 60: 227-274.

LeRoux, M. L., 1933. Parasitisme et caractères sexuels secondaires chez Gammarus pulex L. In: La sexualité des Gammariens. Bull. biol. Fr. Belg., 16 (Suppl.): 1-138.

Muzzall, P. M. \& F. C. Rabelais, 1975. Studies on Acanthocephalus jacksoni Bullock, 1962 (Acanthocephala. Echinorhynchidae), 1. Seasonal periodicity and new host records. Proc. helminth. Soc. Wash., 42 (1): 31-34.

Nicholas, W. L., 1967. The biology of Acanthocephala. Adv. Parasitol., 5: 205-246.

Nicholas, W. L. \& H. B. N. Hynes, 1958. Studies on Polymorphus minutus (Goeze, 1782) as a parasite of domestic duck. Ann. trop. Med. Parasit., 52: 36-47.

Noll, W., 1950. Eine Masseninfektion von Gammarus pulex fossarum Koch mit Polymorphus minutus. Nachr. Sammelstelle Schmarotzerbest. Aschaffenb., 27: 13-15.

Perrin, J.-F., 1976. Ecologie du Haut-Rhône français: Premières données sur le milieu et la faune d'Invertébrés benthiques. D.E.A.-report: 1.37 (Univ. Claude Bernard, Lyon I).

Persat, H., 1976. Principaux aspects de l'écologie de l'ombre commun (Thymallus thymallus (L., 1758)) (Poissons, Salmonidés) : 1-69 (Thesis, Univ. Claude Bernard, Lyon I).

Petrochenko, V. I., 1971. Acanthocephala of domestic and wild animals, I: 1-465; II: $1-478$ (Israel Program for Scientific Translations, Jerusalem, 5901-5902) [translated from the Russian edition 1956-1958].

Podesta, R. B. \& J. C. Holmes, 1970. The life cycles of three polymorphids (Acanthocephala) occurring as juveniles in Hyalella azteca (Amphipoda) at Cooking Lake, Alberta. J. Parasit., 56: 1118-1123.

Roux, A. L., 1970. Le cycle de reproduction de deux espèces étroitement parentes de Crustacés amphipodes: Gammarus pulex et $G$. fossarum. Annls. Limnologie, 6 (1): 27-49.

Rumpus, A. E., 1975. The helminth parasites of the bullhead Cottus gobio (L.) and the stone loach Noemacheilus barbatulus (L.) from the river Avon, Hampshire. J. Fish Biol., 7: 469-483.

Rumpus, A. E. \& C. R. KenNedy, 1974. The effect of the acanthocephalan Pomphorhynchus laevis upon the respiration of its intermediate host Gammarus pulex. Parasitology, Cambridge, 68: 271-284.

SeIdenberG, A. J., 1973. Ecology of the acanthocephalan Acanthocephalus dirus (Van Claeve, 1931) in its intermediate host Asellus intermedius Forbes (Crustacea, Isopoda). J. Parasit., 59: 957-962.

SPENCER, L. T., 1974. Parasitism of Gammarus lacustris (Crustacea, Amphipoda) by Polymorphus minutus (Acanthocephala) in Colorado. Am. Midl. Nat., 91 (2): 505-509.

StaRK, G. T. C., 1965. Diplocotyle (Eucestoda) a parasite of Gammarus zaddachi in the estuary of the Yorkshire Esh, Britain. Parasitology, Cambridge, 55: 415-420.

VIK, R., 1958. Studies on the helminth fauna of Norway, 2. Distribution and life cycle of Cyathocephalus truncatus (Pallas, 1781) (Cestoda). Nytt Mag. Zool., 6: 97-110. 


\section{APPENDIX I}

The occurrence of Acanthocephala in different fish species. For the position of the sampling stations, see appendix II $C .=$ Cyatbocephalus; $M .=$ Metechinorbynchus; Pom. = Pomphorbynchus; Ps. = Pseudoechinorhynchus.

\begin{tabular}{lccc}
\hline Station Date & $\begin{array}{c}\text { Length of } \\
\text { fish }(\mathrm{cm})\end{array}$ & $\begin{array}{c}\text { Acanthocephala } \\
\text { (adults) } \\
\text { number \& species }\end{array}$ & Remarks \\
\hline
\end{tabular}

(a) In THYMALLUS THYMALLUS (grayling):

\begin{tabular}{|c|c|c|c|c|}
\hline A & 28-VII-'75 & 31 & & 6 Pom. laevis \\
\hline A & 2-VIII-'75 & 27 & 7 & 7 Pom. laevis \\
\hline A & 2-VIII-'75 & 32 & & - \\
\hline A & 10-VIII-'75 & 33 & 22 & 2 Pom. laevis \\
\hline B & 27-VIII-'75 & 22 & 23 & 3 Pom. laevis \\
\hline B & 27-VIII-'75 & 24.5 & 3 & 3 Pom. laevis \\
\hline B & 27-VIII-'75 & 38 & 2 & 2 Pom. laevis \\
\hline B & 27-VIII-' 75 & 33 & & - \\
\hline $\mathbf{A}$ & 4-X-75 & 33 & 219 & 9 Pom. laevis \\
\hline C & $12-X-75$ & 37.5 & 157 & 7 Pom. laevis \\
\hline C & $12-\mathrm{X}-75$ & 43 & 280 & 0 Pom. laevis \\
\hline C & $12 \cdot x-75$ & 36 & 197 & 7 Pom. laevis \\
\hline $\mathrm{C}$ & $12-X-75$ & 37 & 185 & 5 Pom. laevis \\
\hline B & $26-X-75$ & 15 & 1 & 1 Pom. laevis \\
\hline B & $26-X-75$ & 14.3 & 30 & 0 Pom. laevis \\
\hline B & $26-X-75$ & 13.5 & 40 & o Pom. laevis \\
\hline B & $26-X=75$ & 14.5 & 60 & 0 Pom. laevis \\
\hline B & $26-X-75$ & 13 & 40 & Pom. laevis \\
\hline $\mathbf{A}$ & $26-X-75$ & 15 & 60 & o Pom. laevis \\
\hline A & $26-X-75$ & 26.3 & 46 & 6 Pom. laevis \\
\hline A & 26-X-75 & 28 & & - \\
\hline$A$ & $26-x-75$ & 27.8 & 120 & Pom. laevis \\
\hline $\mathrm{A}$ & 1-XI-'75 & 27 & 128 & Pom. laevis \\
\hline A & 1-XI-'75 & 28 & 55 & Pom. laevis \\
\hline A & $1-\mathrm{XI}-75$ & 29 & 145 & 5 Pom. laevis \\
\hline A & 8-XI-'75 & 29 & 177 & 7 Pom. laevis \\
\hline A & 8-XI-'75 & 28 & 74 & Pom. laevis \\
\hline A & 8-XI-'75 & 27 & 172 & Pom. laevis \\
\hline $\mathbf{A}$ & 8-XI-'75 & 18.5 & 11 & Pom. laevis \\
\hline A & 8-XI-'75 & 16.5 & 20 & Pom. laevis \\
\hline A & 8-XI-'75 & 14 & 34 & (1 Pom. laevis \\
\hline B & 14-III-' 76 & 29.3 & 160 & Pom. laevis \\
\hline B & 14-III-'76 & 32.2 & 206 & Pom. laevis \\
\hline B & 14-III-'76 & 30.7 & 220 & Pom. laevis \\
\hline B & $14-$ III-' 76 & 28 & 210 & Pom. laevis \\
\hline B & 14-III-' 76 & 32 & 150 & Pom. laevis \\
\hline B & 14-III-'76 & 33.5 & 305 & Pom. laevis \\
\hline B & 14-III-' 76 & 27 & 228 & Pom. laevis \\
\hline B & 14-III-'76 & 28.7 & 112 & Pom. laevis \\
\hline B & 3-IV-76 & 32 & 190 & Pom. laevis \\
\hline B & 3-IV:'76 & 36 & $\begin{array}{r}260 \\
4\end{array}$ & $\begin{array}{l}\text { Pom. laevis, } \\
\text { M. truttae }\end{array}$ \\
\hline B & 8-IV-'76 & 33.5 & 259 & Pom. laevis \\
\hline B & 8-IV:'76 & 31 & 190 & Pom. laevis \\
\hline B & 8-IV:'76 & 29.5 & 38 & Pom. laevis \\
\hline B & 8-IV:76 & 28.7 & 6 & Pom. laevis \\
\hline B & 8-IV:'76 & 34 & 97 & Pom. laevis \\
\hline $\mathbf{B}$ & $8-I V=76$ & 27.8 & 43 & Pom. laevis \\
\hline B & 8-IV:'76 & 31.5 & 31 & Pom. laevis \\
\hline B & 8-IV-'76 & 26.8 & 4 & Pom. laevis \\
\hline $\mathrm{D}$ & 14-IV-'76 & 30 & 64 & M. truttae \\
\hline $\mathrm{D}$ & 14-IV:'76 & 34 & $\begin{array}{r}3 \\
121\end{array}$ & $\begin{array}{l}\text { Pom. laevi } \\
\text { M. truttae }\end{array}$ \\
\hline
\end{tabular}

in stomach: 1 cystacanth larva stomach content: mainly insects stomach content: mainly insects in stomach: 5 cystacanth larvae cysts on intestinal wall cysts on intestinal wall cysts on intestinal wall cysts on intestinal wall in stomach: 1 cystacanth larva; insects

cysts on intestinal wall cysts on intestinal wall cysts on intestinal wall intestine removed

even swim bladder affected even liver affected swim bladder also affected in stomach: 5 cystacanth larvae; in intestine: 30 worms $/ \mathrm{cm}^{2}$ ! in stomach: 21 cystacanth larvae; 2 acanthella larvae intestine removed; in stomach: 5 cystacanth larvae; insects

in stomach: 6 cystacanth larvae

in stomach: 32 cystacanth larvae; 2 acanthella larvae; gammarids in stomach: 3 cystacanth larvae; insects

in stomach: 48 cystacanth larvae; 2 acanthella larvae; gammarids in stomach: 30 cystacanth larvae

in stomach: 23 cystacanth larvae

in stomach: 1 acanthella larva; insects

in stomach: 2 cystacanth larvae

cysts on intestinal wall

cysts on intestinal wall

in stomach: insects

gonads affected as well; in pars pylorica: C. truncatus (Cestoda) cysts on intestinal wall cysts on intestinal wall mature worms (gravid $\%$ \%)

small worms; many cysts on intestinal wall small worms; many cysts on intestinal wall mature worms

in stomach and pars pylorica: C. truncatus (Cestoda) 


\begin{tabular}{|c|c|c|c|c|c|}
\hline Station & Date & $\begin{array}{l}\text { Length of } \\
\text { fish }(\mathrm{cm})\end{array}$ & $\begin{array}{l}\text { Acanthocephala } \\
\text { (adults) } \\
\text { number \& species }\end{array}$ & & Remarks \\
\hline $\mathrm{D}$ & $14-\mathrm{IV} \cdot 76$ & 27.5 & $\begin{array}{l}1 \text { Pom. laevis, } \\
29 \text { M. truttae }\end{array}$ & \multicolumn{2}{|c|}{ in stomach: C. truncatus (Cestoda) } \\
\hline $\mathbf{E}$ & 27-IV-'76 & 29.5 & - & \multicolumn{2}{|l|}{ in stomach: mainly insects } \\
\hline $\mathbf{E}$ & 27-IV-'76 & 32 & 1 Pom. laevis & & \\
\hline $\mathrm{E}$ & 27-IV-'76 & & 2 Pom. laevis & & \\
\hline $\mathbf{E}$ & 27-IV-'76 & 31 & - & \multicolumn{2}{|l|}{ in stomach: mainly insects } \\
\hline $\mathrm{E}$ & 27-IV:'76 & 31 & 2 Pom. laevis & \multicolumn{2}{|l|}{ in stomach: insects } \\
\hline $\mathbf{E}$ & 27-IV-'76 & 30.5 & 1 Pom. laevis & \multicolumn{2}{|l|}{ in stomach: insects } \\
\hline \multicolumn{6}{|c|}{ (b) In BARBUS BARBUS (barbel): } \\
\hline G & 14-XII-'75 & 42.5 & Pom. laevis & \multicolumn{2}{|c|}{ mature worms (gravid $\%$ \%) } \\
\hline G & 14-XII-'75 & 48.5 & Pom. laevis & \multicolumn{2}{|c|}{ mature worms (gravid o o ) } \\
\hline $\mathbf{G}$ & 14-XII-'75 & 40.5 & Pom. laevis & \multicolumn{2}{|c|}{ many cysts on intestinal wall } \\
\hline $\mathbf{G}$ & 14-XII-'75 & 37 & 23 Pom. laevis & \\
\hline $\mathbf{G}$ & 14-XII-'75 & & 23 Pom laevis & & \\
\hline $\mathbf{G}$ & 14-XII-'75 & 42.5 & 150 Pom. laevis & & . \\
\hline G & 14-III-'76 & 33 & 8 Pom. laevis & \multirow{2}{*}{\multicolumn{2}{|c|}{$\begin{array}{l}\text { mature worms (gravid } \\
\text { cysts on intestinal wall }\end{array}$}} \\
\hline $\mathbf{G}$ & 14-III-'76 & 31 & 19 Pom. laevis & & \\
\hline \multicolumn{6}{|c|}{ (c) In other fish species (as specified): } \\
\hline \multicolumn{6}{|c|}{ Species of fish } \\
\hline B & 27-VIII-'75 & \multicolumn{2}{|c|}{ Salmo trutta } & $\begin{array}{l}22 \text { Pom. laevis, } \\
1 \text { M. truttae }\end{array}$ & cysts of Pom. laevis on intestinal wall \\
\hline B & 27-VIII-'75 & \multicolumn{2}{|c|}{ Salmo trutta } & 28 Pom. laevis & \\
\hline B & 14-XII-'75 & \multicolumn{2}{|c|}{ Rutilus rutilus $(20 \mathrm{~cm})$} & 1 Pom. laevis & many cysts on intestinal wall \\
\hline B & 8-IV:76 & \multicolumn{2}{|c|}{ Phoxinus phoxinus $(6 \mathrm{~cm})$} & 3 Pom. laevis & \\
\hline $\mathbf{B}$ & 8-IV-'76 & \multicolumn{2}{|c|}{ Pboxinus phoxinus ( $5 \mathrm{~cm}$ ) } & 1 Pom. laevis & \\
\hline $\mathbf{F}$ & 14-IV-'76 & \multicolumn{2}{|c|}{ Cottus gobio } & 13 Pom. laevis & in stomach: 6 cystacanth larvae \\
\hline $\mathbf{E}$ & 27-IV-'76 & \multicolumn{2}{|c|}{ Lota lota } & $\begin{array}{r}136 \text { Ps. clavula, } \\
1 \text { Pom. laevis }\end{array}$ & also in pars pylorica many $P_{s}$. clavula \\
\hline B & $25-V \cdot 76$ & \multicolumn{2}{|c|}{ Noemacbeilus barbatulus } & 1 Pom. laevis & \\
\hline
\end{tabular}

\section{APPENDIX II}

Position of the sampling stations

\begin{tabular}{|c|c|c|}
\hline Station & Position & Department \\
\hline$A$ & River Ain, E. of Villieu & Ain \\
\hline B & $\begin{array}{l}\text { River Ain, near Gévrieux, downstream } \\
\text { of the bridge on R.N. } 504\end{array}$ & Ain \\
\hline C & River Ain, near Chazey-sur-Ain & Ain \\
\hline D & $\begin{array}{l}\text { River Furans, near Chazey-Bons, N. of } \\
\text { Belley }\end{array}$ & Ain \\
\hline $\mathbf{E}$ & $\begin{array}{l}\text { River Loue, near Parcey, S. of Dole, E. } \\
\text { of Beaune }\end{array}$ & Jura \\
\hline F & $\begin{array}{l}\text { River Rhône, near Pont de Jons, N.E. } \\
\text { of Lyon }\end{array}$ & Ain/Rhône \\
\hline $\mathbf{G}$ & $\begin{array}{l}\text { River Albarine, near Gévrieux, not far } \\
\text { from its confluence with the river Ain }\end{array}$ & Ain \\
\hline $\mathrm{H}$ & $\begin{array}{l}\text { River Merloux, a small stream S.W. of } \\
\text { Villefranche-sur-Saône }\end{array}$ & Rhône \\
\hline
\end{tabular}

